\title{
Debunking Cannabidiol as a Treatment for COVID-19: Time for the FDA to Adopt a Focused Deterrence Model?
}

\author{
Chelsea L. Shover ${ }^{1}$, Keith Humphreys ${ }^{1}$ \\ 1. Psychiatry and Behavioral Sciences, Stanford University School of Medicine, Palo Alto, USA
}

Corresponding author: Chelsea L. Shover, clshover@stanford.edu

\begin{abstract}
Many cannabidiol (CBD) retailers make unsupported medical claims about their product. In recent years, the U.S. Food and Drug Administration (FDA) has sent warning letters to CBD retailers who promoted CBD to treat Alzheimer's disease, cancer, diabetes, and other serious conditions for which there is no evidence of its efficacy as a treatment or preventive. Compliance with these warning letters has been low. During the novel coronavirus disease 2019 (COVID-19) pandemic, the FDA has begun sending more strongly worded warning letters that appear to have better compliance in that most of these companies have removed COVID-19related claims. However, many continue to present other unsupported medical claims on other serious medical conditions like cancer, depression, addiction, and bone fractures, among many others. We argue that adopting a strategy of focused deterrence where the FDA prioritizes enforcement related to COVID-19 claims - but when COVID-19-related claims are found, pursues all other violations by that company - would present an opportunity to efficiently cut down on harmful claims overstating CBD’s benefits.
\end{abstract}

Categories: Infectious Disease, Public Health

Keywords: cannabidiol, health policy, food and drug administration, cannabis, covid-19, regulation

\section{Editorial}

Over the past few years, the U.S. Food and Drug Administration (FDA) has sent warning letters to some cannabidiol (CBD) retailers instructing them to cease making unsubstantiated therapeutic claims regarding many diseases, including cancer, addiction, and diabetes [1]. These letters asked recipients to respond in writing within 15 days and appear to have been largely ignored, as CBD retailers continue making unsupported claims about their product's ability to treat or prevent a variety of serious conditions. In March, the FDA began responding to unsupported therapeutic claims about CBD and novel coronavirus disease 2019 (COVID-19) by sending more strongly worded warning letters that instruct recipients to withdraw such claims within 48 hours [1]. The FDA has limited regulatory capacity to police the numerous CBD retailers and the even larger number of unsupported therapeutic claims about CBD and other cannabis-derived products, so it is worth considering whether this is an efficient, high-impact strategy [2,3].

Received 05/18/2020

Review began 05/26/2020 Review ended 06/05/2020 Published 06/17/2020

\section{(c) Copyright 2020}

Shover et al. This is an open access article distributed under the terms of the Creative Commons Attribution License CC-BY 4.0., which permits unrestricted use, distribution, and reproduction in any medium, provided the original author and source are credited.
To examine whether COVID-19-related letters led to faster and more complete compliance, on April 30, 2020, we reviewed the websites and social media of all CBD retailers who received an FDA warning letter in 2019 or 2020. We expected that a greater proportion of CBD manufacturers that received the strongly worded COVID-19-related warning letters would have removed unsupported medical claims compared to CBD manufacturers that received the letters regarding other unsubstantiated therapeutic claims. We compared the proportion of companies that removed claims or added prominent disclaimers (i.e., positioned near the product and stating that the FDA had not evaluated the claims and products were not intended to diagnose, prevent, or treat disease) by type of warning letter.

In 2019 and 2020, the FDA sent 18 letters to companies about "Unapproved New Drugs/Misbranded/Cannabidiol (CBD) Products." The recipients included manufacturers and retailers, with many companies doing both. Notably, at least one of the recipients (Curaleaf, Wakefield, MA) operates cannabis dispensaries around the United States in addition to selling CBD online via Curaleaf Hemp, which was cited in the 2019 warning letter. As of April 30, 2020, half (nine) of these companies still marketed CBD as treating or preventing disease without disclaimers. Between March 6, 2020, and April 27, 2020, the FDA sent COVID-19-related warning letters related to 38 companies, $21 \%$ (eight) of which had CBD products for sale on their website. As of April 30, 2020, six of the eight companies had either removed the COVID-19related statements or added prominent disclaimers on the same page as the statements.

However, half of these companies had other medical claims similar to those for which the 2019 companies had been cited (Table 1). Conversely, three of the companies that received letters in 2019 had recently added new content marketing CBD products as protective against COVID-19, or claiming CBD improves immunity generally. 


\section{Cureus}

\begin{tabular}{|c|c|c|c|c|}
\hline Company & Citation & Date & CoVID-19-related content & $\begin{array}{l}\text { Other medical claims (up to one } \\
\text { example per company) }\end{array}$ \\
\hline $\begin{array}{l}\text { Homero Corp DBA } \\
\text { Natures CBD Oil } \\
\text { Distribution, } \\
\text { Manchester, NH }\end{array}$ & $\begin{array}{l}\text { CBD Letter: Unapproved New } \\
\text { Drugs/Misbranded/Cannabidiol } \\
\text { (CBD) Products }\end{array}$ & $4 / 20 / 20$ & & $\begin{array}{l}\text { "CBD oil is being discovered to work for } \\
\text { numerous health issues, but it is anxiety } \\
\text { that it seems to work most effectively. } \\
\text { Though medications provided from the } \\
\text { pharmaceutical companies and the } \\
\text { medical community can be beneficial, } \\
\text { there are side effects and the concern } \\
\text { for addiction with regular use. There is } \\
\text { an array of advantages associated with } \\
\text { CBD oil as a treatment for anxiety. } \\
\text { Studies show that } 1 \text { single dose is } \\
\text { efficient and quick and does not have to } \\
\text { be used on a daily basis. Other benefits } \\
\text { for anxiety sufferers is that if traditional } \\
\text { medication fails or cannot be tolerated } \\
\text { CBD offers hope for those stuck with no } \\
\text { solution. For those who want to add } \\
\text { CBD to a traditional medicine to give it a } \\
\text { boost, there is no evidence that CBD } \\
\text { cannot interact with other drugs and } \\
\text { can be used safely." }\end{array}$ \\
\hline $\begin{array}{l}\text { Nova Botanix LTD DBA } \\
\text { CanaBD, London }\end{array}$ & $\begin{array}{l}\text { COVID-19 Letter: Unapproved } \\
\text { Products Related to the } \\
\text { Coronavirus Disease } 2019 \\
\text { (COVID-19) }\end{array}$ & $4 / 16 / 20$ & $\begin{array}{l}\text { "Current situation has been } \\
\text { striking fear and anxiety } \\
\text { amongst many as it goes on a } \\
\text { rampage around the world. } \\
\text { CBD works with your body to } \\
\text { regulate optimal functionality } \\
\text { of the receptors that are } \\
\text { connected to anxiety, stress } \\
\text { and sleep disorders. In } \\
\text { addition, CBD may strengthens } \\
\text { [sic] your immune system by } \\
\text { promoting an overall healthier } \\
\text { wellbeing." }\end{array}$ & $\begin{array}{l}\text { "In addition, CBD is known to treat } \\
\text { these conditions: joint pain, arthritis, } \\
\text { autoimmune disorder, diabetes, high } \\
\text { blood pressure, depression, migraines, } \\
\text { Crohn's and colitis, inflammation, } \\
\text { nausea, Parkinson's, rheumatism, skin } \\
\text { conditions." }\end{array}$ \\
\hline $\begin{array}{l}\text { Gaia Arise Farms } \\
\text { Apothecary, } \\
\text { Waynesville, NC }\end{array}$ & COVID-19 Letter & $4 / 13 / 20$ & & $\begin{array}{l}\text { "CBD from cannabis improves } \\
\text { inflammatory, spastic, and nerve pain, } \\
\text { (2) it provides restful sleep, (3) reduction } \\
\text { of nightmares for those with PTSD, (4) it } \\
\text { reduces anxiety, which causes muscle } \\
\text { tension, (5) helps relieve Opioid } \\
\text { Addiction, in case the real doctors (or } \\
\text { drug dealers) got you hooked. (6) But l'd } \\
\text { use our Addiction Protocol, to heal that } \\
\text { addiction, along with True Pain Relief } \\
\text { w/CBD for the chronic pain." }\end{array}$ \\
\hline Earthley, Columbus, $\mathrm{OH}$ & COVID-19 Letter & $4 / 9 / 20$ & $\begin{array}{l}\text { "A LOT of people are worried } \\
\text { about coronavirus right now. It } \\
\text { doesn't help that no one } \\
\text { seems to know exactly what } \\
\text { the truth is. We also don't } \\
\text { know what will happen if or } \\
\text { when it dramatically spreads in } \\
\text { the US. However, we do NOT } \\
\text { think it's time to panic. But if it } \\
\text { helps you to feel like you're } \\
\text { ready, just in case ... we're } \\
\text { here. And so we're giving away } \\
\text { an Immune Support Collection } \\
\text { to one lucky winner!" }\end{array}$ & $\begin{array}{l}\text { "Experience true relief of back pain, } \\
\text { muscle pain, joint pain, and more. Our } \\
\text { synergistic cream combines naturally } \\
\text { pain-relieving herbs like St. John's Wort } \\
\text { and yarrow with full-spectrum CBD. } \\
\text { Rub a small amount into the sore spot } \\
\text { and feel better soon!" }\end{array}$ \\
\hline & & & $n$-yian is a & \\
\hline
\end{tabular}




\section{Cureus}

\begin{tabular}{|c|c|c|c|c|}
\hline $\begin{array}{l}\text { CBD Online Store, } \\
\text { Laguna Hills, CA }\end{array}$ & COVID-19 Letter & $4 / 7 / 20$ & $\begin{array}{l}\text { superfood that boost and } \\
\text { support the immune system } \\
\text { [sic]. Adding CBD, nature's } \\
\text { strongest anti-inflammatory, } \\
\text { will keep your body from } \\
\text { becoming inflamed when it } \\
\text { throws all it can at a disease, } \\
\text { decreasing your risks even } \\
\text { more." }\end{array}$ & $\begin{array}{l}\text { "Study: \#CBD Helps } \\
\text { Heal \#Bone \#Fractures. What a } \\
\text { miraculous molecule CBD is!" }\end{array}$ \\
\hline $\begin{array}{l}\text { Indigo Naturals, Seattle, } \\
\text { WA }\end{array}$ & COVID-19 Letter & $4 / 6 / 20$ & $\begin{array}{l}\text { From blog post, "Can CBD } \\
\text { help with viral cytokine } \\
\text { storm?": "In inflammatory } \\
\text { states (such as cytokine } \\
\text { storm), CBD can calm } \\
\text { inflammation." (Post is tagged: } \\
\text { Can CBD help with the } \\
\text { cytokine storm response; } \\
\text { Covid19 or coronavirus and } \\
\text { cytokine storms; the } \\
\text { endocannabinoids system and } \\
\text { immune response to } \\
\text { coronavirus.) }\end{array}$ & $\begin{array}{l}\text { "Here's the running list of CBD benefits: } \\
\text { CBD benefits for Addiction; CBD } \\
\text { benefits for Allergies and Histamines; } \\
\text { CBD benefits for Anxiety (\#1!); CBD } \\
\text { benefits for Arthritis; CBD benefits for } \\
\text { Autoimmune Disease and the Immune } \\
\text { System; CBD benefits for Blood } \\
\text { Pressure; CBD benefits for Cancer (\#5); } \\
\text { CBD benefits for Dementia and } \\
\text { Alzheimer's; CBD benefits for } \\
\text { Depression; CBD benefits for } \\
\text { Diabetes." }\end{array}$ \\
\hline $\begin{array}{l}\text { Native Roots Hemp, } \\
\text { Algoma, WI }\end{array}$ & COVID-19 Letter & $4 / 6 / 20$ & & $\begin{array}{l}\text { "Studies show CBD oil helps with: } \\
\text { addiction, anxious feelings, appetite, } \\
\text { behavioral issues, blood circulation, } \\
\text { blood sugar regulation, bone health, } \\
\text { cardio health, cellular health, circulatory } \\
\text { health, compulsiveness, digestive } \\
\text { health, endocrine health, eye health, } \\
\text { focus, inflammation, joint discomfort, } \\
\text { kidney function, liver function, lymphatic } \\
\text { health, lung health, memory loss, mood } \\
\text { stability, motion sickness, muscle } \\
\text { degeneration, nervous system health, } \\
\text { reproductive health, respiratory health, } \\
\text { skin health, sleeplessness, traumatic } \\
\text { stress, weight management." }\end{array}$ \\
\hline $\begin{array}{l}\text { NeuroXPF, Las } \\
\text { Vegas, NV }\end{array}$ & CoVID-19 Letter & $3 / 31 / 20$ & $\begin{array}{l}\text { "Energize your immune system } \\
\text { by igniting your } \\
\text { endocannabinoid system with } \\
\text { CBD! Learn more at } \\
\text { http://NeuroXPF.com" }\end{array}$ & $\begin{array}{l}\text { "Research has shown that CBD can } \\
\text { improve brain functions and even heal } \\
\text { brain tissue damaged by TBIs. Take } \\
15 \% \text { off your order at } \\
\text { http://NeuroXPF.com in honor of } \\
\text { \#BrainInjuryAwarenessMonth with } \\
\text { coupon code: cbd4brain" }\end{array}$ \\
\hline $\begin{array}{l}\text { Mr. Pink Collections, } \\
\text { LLC, Beverly Hills, CA }\end{array}$ & CBD Letter & $11 / 22 / 19$ & & $\begin{array}{l}\text { "Not only CBD oil can help to relieve } \\
\text { health problems such as anxiety, } \\
\text { depression, reduce seizures and also } \\
\text { combat insomnia but it can also help } \\
\text { for muscle recovery." }\end{array}$ \\
\hline $\begin{array}{l}\text { Whole Leaf } \\
\text { Organics, Sherman } \\
\text { Oaks, CA }\end{array}$ & CBD Letter & $11 / 22 / 19$ & & $\begin{array}{l}\text { "CBD-EX combines the best in cancer } \\
\text { fighting elements, into one simple } \\
\text { capsule." "Our formulations have been } \\
\text { proven to be effective at reducing } \\
\text { inflammation, and minimizing the way } \\
\text { cancer cells manipulate neighbor cells - } \\
\text { the key factor in being successful when } \\
\text { trying to be proactive against disease." }\end{array}$ \\
\hline $\begin{array}{l}\text { Infinite Product } \\
\text { Company } \\
\text { LLLP, Lakewood, CO }\end{array}$ & CBD Letter & $11 / 22 / 19$ & $\begin{array}{l}\text { Now selling "Nano CBD Hand } \\
\text { Sanitizer" }\end{array}$ & \\
\hline
\end{tabular}




\section{Cureus}

\section{Organix}

Industries/Plant

Organix, San

CBD Letter

$11 / 22 / 19$

Bernardino, CA

\section{Red Pill}

Medical, Phoenix, AZ

CBD Letter

$11 / 22 / 19$

CDRL Nutritional

Inc, Concord, CA

CBD Letter

$11 / 22 / 19$

Private I

Salon, Charlotte, NC

CBD Lette

Rooted

Apothecary, Naples, FL
CBD Letter methods to ease side effects of diseases, illnesses, and ailments including leukemia, all types of cancers, stress, anxiety, joint pain, seizures, inflammation, sleep apnea, high blood pressure and the list goes on."

"When CBD reaches a family of receptors, or cells that receive stimuli, called vanilloid receptors, the interaction results in lower inflammation and levels and pain perception, according to a study published in Current Neuropharmacology. And a study published in July 2016 in the European Journal of Pain found that CBD could help people with arthritis manage their pain. The animal study looked at whether using a CBD gel transdermally (on the skin) would reduce inflammation and signs of pain, and researchers concluded that the topical product did offer relief from pain-related behaviors without evidence of side effects."

"CBD is a powerful antioxidant that has several beneficial applications to help you with: anxiety, alcoholism, back pain, chronic pain, diabetes,

depression, epilepsy, fibromyalgia, migraine, multiple sclerosis, PTSD, psoriasis, rheumatoid arthritis, schizophrenia \& psychosis, and much more,"

"Although inflammation is often seen in a negative light, it's a vital immune response to infection.... Therefore, preventing inflammation when it is actually needed can lower immune function and make people more susceptible to disease. CBD and other cannabinoids may be able to help balance that function in the body."

"Save up to $40 \%$ - Corona

Relief Efforts. No one planned on this. We recently ran a discount and to those of you who purchased product, we continue to be thankful for your support. Now it's our turn to go a step further. We are offering our biggest discount ever! The economic impact is widespread, the fear is more 10/10/19 contagious than anything else, and who knows when things will 'normalize.' But, we do know the science behind hemp-derived CBD and how it interacts with the

Endocannabinoid System in each one of us. Right now,
"The receptors that $\mathrm{CBD}$ oil targets are in the endo-cannabinoid system, which can be found in the nervous system, digestive system, in your brain, and throughout your entire body. When your endo-cannabinoid system is not balanced, you suffer from things like stress, depression, hypertension, fatigue, migraines, chronic pain, and more." 


\section{Cureus}

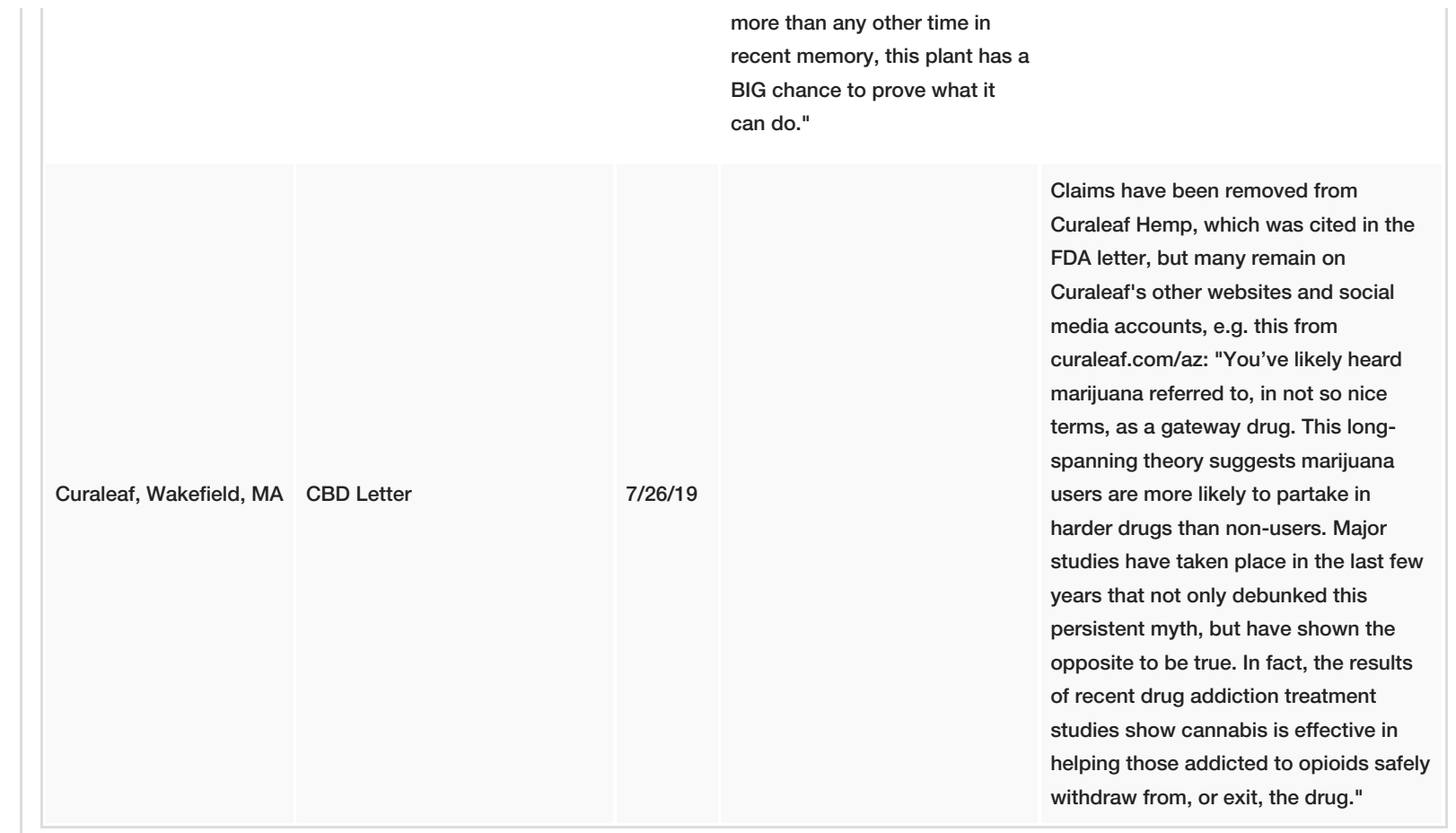

TABLE 1: Online content of CBD retailers that received warning letters from the U.S. Food and Drug Administration

CBD, cannabidiol; PTSD, posttraumatic stress disorder; TBI, traumatic brain injury

Our rapid online review comparing the compliance with these two types of FDA warning letters suggests that the FDA might profitably adopt a "focused deterrence" strategy, which police sometimes use to deter gang violence [4].

A focused deterrence strategy involves publicly telling potential offenders what the number one enforcement priority is (in the police case, typically gun violence; in this case, COVID-related claims) and if anyone breaks the rule, the offender is investigated for all transgressions, even otherwise low-priority ones. A focused deterrence strategy has two effects. First, because the certainty that penalties will occur is more deterrent than a probabilistic threat of even severe punishment, announcing that COVID-19 is the highest priority will prevent other CBD retailers from making such claims in the first place. Second, the marginal cost of expanding enforcement when intervening against CBD claims (i.e., expanding said letters to cover all of that same retailer's unsupported claims about a range of diseases) is modest, allowing the FDA to completely clean up the worst actors in the industry.

Our review highlighted a few other ways that focused deterrence adopted during a pandemic could have lasting effects even after the acute threat of COVID-19 has diminished. (1) The FDA might consider requiring a response within 48 hours for all misbranded CBD drug products. (2) Several of the companies that received warning letters in 2019 had removed the original offending content but were now selling products aimed at treating or preventing COVID-19 (Table 1). These types of claims and promotions presumably fall under the area of what companies were instructed to avoid in the future. Publicly adopting focused deterrence can reinforce the gains made by earlier enforcement without having to necessarily individually re-contact the CBD companies that have been previously cited. (3) The FDA may consider expanding letters to cover all websites operated by a company it is citing. Curaleaf provides a useful example. Cited in July for its subsidiary Curaleaf Hemp, Curaleaf manufacturers CBD and cannabis products and operates dispensaries in several states. The dispensaries were not mentioned in the warning letter, and despite removing CBDrelated medical claims from the cited website, medical claims about cannabis products were still present on Curaleaf's state websites and social media as of April 30, 2020. Again, it would require only marginal additional resources for FDA to expand the warning to cover all such claims from a retailer, including when they are made on a different subsidiary's website.

In conclusion, we found that FDA letters regarding non-COVID-focused claims by CBD retailers have made little impact - few letters have been sent and nearly half have been ignored. But the stricter COVID-19 letters were complied with at a higher rate, despite the much shorter time window since they were sent. However, the fact that about half of the retailers that received COVID-19 letters still had other unsupported 
medical claims on their websites or social media is concerning. This suggests that significant public health benefit at marginal cost could be garnered if FDA letters sent in response to COVID-19 claims were amended to encompass all unsupported therapeutic claims made by recipients. Moreover, making it explicit and public that this focused deterrence strategy was being employed could prevent the industry as a whole from making COVID-19-focused claims in the first place.

\section{Additional Information \\ Disclosures}

Conflicts of interest: In compliance with the ICMJE uniform disclosure form, all authors declare the following: Payment/services info: CLS was supported by National Institute on Drug Abuse under grant T32 DA035165, and the Wu Tsai Neurosciences Institute at Stanford University. KH was supported by grants from the U.S. Veterans Health Administration and the Wu Tsai Neurosciences Institute. Financial relationships: All authors have declared that they have no financial relationships at present or within the previous three years with any organizations that might have an interest in the submitted work. Other relationships: All authors have declared that there are no other relationships or activities that could appear to have influenced the submitted work.

\section{References}

1. U.S. Food and Drug Administration warning letters. (2020). Accessed: April 30, 2020: https://www.fda.gov/inspections-compliance-enforcement-and-criminal-investigations/complianceactions-and-activities/...

2. Allem JP, Escobedo P, Dharmapuri L: Cannabis surveillance with Twitter data: emerging topics and social bots. Am J Public Health. 2020, 110:357-362. 10.2105/ajph.2019.305461

3. Caputi TL: The medical marijuana industry and the use of "research as marketing" . Am J Public Health. 2020, 110:174-175. 10.2105/AJPH.2019.305477

4. Kennedy DM: Deterrence and Crime Prevention (1st Edition), Routledge Studies in Crime and Economics . Routledge, Oxford, UK; 2009. 